\title{
Legal issues concerning mine closure and social responsibility on the West Rand
}

\author{
ES VAN EEDEN, M LIEFFERINK JF DURAND*
}

\begin{abstract}
Mining and, especially, gold and uranium mining have played a major role in the economy, history, and demography of South Africa. The contribution of the mines to the economy of South Africa over the past century has been overvalued, while the social injustices and negative environmental impacts that accompanied mining have been underplayed or ignored by the mining houses and government. The environmental situation has worsened significantly over the past few years due to the abandonment and pending closure of most of these mines. A reluctance is perceived on the part of the mining companies, and even government, to take responsibility for the damage caused by pollution, ecological degradation, and impact on human health by mining. Instead, the current informal policy appears to take smaller companies to court on minor environmental injustices to, perhaps, impress the broader public, while one of the biggest environmental concerns is stylishly treated. The inability of government to address the damage by mines effectively is in conflict with the National Water Act, the National Environmental Management Act, the Mineral and Petroleum Resources Act, the National Nuclear Regulator Act, and the Constitution of South Africa. The authors propose a multidisciplinary approach to address water-related environmental injustices on the West Rand and Far West Rand. We also describe the application of the National Environmental Management Act of South Africa (Act No. 107 of 1998) in the Wonderfonteinspruit and Tweelopiespruit Catchments and the current water quality situation.
\end{abstract}

Keywords: Environmental Acts; Legal environmental issues; mining closure; West Rand; environmental health; Wonderfonteinspruit; Tweelopiespruit

Disciplines: History; Health Sciences; Legal Sciences; Economic Sciences; Environmental Sciences

\section{Introduction}

Since the establishment of the environmental movement in 1964 abroad, the understanding of the interrelationship between humans and their environment has grown progressively more complex (Benton and Short, 2000; White, 1970; Attfield, 1983, 1994; Goudswaard, 1979). Past and current actions by primary regulators, decision-makers, capitalists,

* In alphabetic order: Dr JF (Francois) Durand is a member of staff in the Department of Zoology at the University of Johannesburg, South Africa. Ms Mariette Liefferink is chief executive director of the Federation for a Sustainable Environment, South Africa. Prof. Elize $\mathrm{S}$ van Eeden is a member of the Research Niche Area for the Cultural Dynamics of Water at North-West University, South Africa. Email: elise.vaneeden@nwu.ac.za. 
scientists, and an ignorant public create a complex array of interactions, which is set in a political, socio-economic, scientific, and legal matrix (Adler et al., 2007). To exacerbate the complexity of the situation, the injurers and injured think differently about the solution to these environmental and socio-economic problems (Van Eeden, 2007a; 2007b).

According to Funke et al. (2007), the attempts of government departments to engage mining companies in the rehabilitation of the environment have been frustrated because of their refusal to take responsibility for acid mine drainage and other environmental and health problems associated with mining (Van Eeden, 2006; Van Eeden, 2007b; Van Eeden, Liefferink \& Tempelhoff, 2008). Before and during the apartheid era, followed by a period of political isolation and economic sanctions, the government of the day always nurtured its relationship with the mining industry, which benefited both parties (Van Eeden, 2006; Van Eeden, 2008a). Both parties always benefited economically from this relationship, while the government turned a blind eye to the environmentally and socially harmful practices of the mines. Adler et al. (2007) argue that mining companies have held their production costs artificially low by opting for the deflection of certain costs such as the rehabilitation of the environment and social welfare to the state and third parties. Many gold mines had been abandoned or had become insolvent before the full environmental and socio-economic impacts caused by them became evident and, thus, cannot be legally compelled to remediate these negative impacts.

Water-related remediation studies should include a consideration of environmental ethics, environmental responsibilities, liability, and equity (Gutmann and Thompson, 2006; Van Eeden \& Brink, 2007). This approach could change the situation of conflict to cooperative efforts between the gold mining companies, conservationists, activists, and inhabitants in the study area (Van Eeden \& Brink, 2007). Over the past century, toxic and radioactive material have emanated from the gold mines in western Gauteng (parts of the West Rand) and North West Province (parts of the Far West Rand) into the Wonderfonteinspruit and Tweelopiespruit (spruit $=$ stream) at concentrations that exceed average surface abundances.

Urbanisation in the area increased in conjunction with mining and associated industries, which were established after 1930 in the vicinity of the Wonderfonteinspruit and Tweelopiespruit. Urbanisation continued until people were living and working only tens of metres away from mine deposits, which, in 2007, were identified as radioactive sites by the National Nuclear Regulator of South Africa (Van Eeden, 1992; 2008a). The closure of some mines and the non-compliance with laws stipulating rehabilitation of mine tailings, slimes dumps, and land have exacerbated the situation. Water containing mine effluent is currently decanting from shafts, boreholes, and springs due to the cessation of the pumping of water from the mine void in the Central Rand and West Rand (Van Biljon and Krige, 2005).

Some communities living in the rural areas adjacent to the mines in western Gauteng and North West Province are dependent on groundwater from boreholes due to the lack of municipal water. The farming communities and people living in informal settlements use groundwater and surface water for drinking purposes, to water livestock, and to irrigate crops. In cases where the water used for irrigation is contaminated by 
mine effluent, the potential exists for metal bioaccumulation in crops and consequently, this would pose a human health risk (Van Biljon, 2007; Van Eeden, 2006). Environmental studies, which include water and sediment analyses, and radioactivity and biodiversity surveys have been done on the Wonderfonteinspruit and Tweelopiespruit over the past few years (Coetzee et al., 2006; Fourie, 2005; 2006; Graham, 2007; Heyl, 2007; Hobbs and Cobbing, 2007; National Nuclear Regulator, 2007; Oelofse et al., 2007; Council for Geoscience Archive, FWRDWA, 1964-1984; Council for Geoscience Archive, SCTC, 1964-2004).

\section{Some negative impacts of mining on the Wonderfonteinspruit and Tweelopiespruit Catchments}

This section includes a short summary of some of the major impacts of mines on the West Rand on the Wonderfonteinspruit and Tweelopiespruit Catchments (which have already been discussed in several articles) and their effect on the natural environment and the communities dependent on these water sources.

\subsection{Abstraction and discharging of water from gold mines}

Mine effluent emanating from mines on the West Rand affects the Vaal River to the south and the Limpopo River to the north, due to the fact that tributaries of both originate at the Continental Water Divide (Coetzee et al., 2006) ("intercontinental surface water divide" Hobbs \& Cobbing, 2007). The mine effluent generated by mines on the West Rand also has a negative impact on the quality of groundwater because large portions of mine land in Gauteng and North West Province and the rivers that flow from this land occur close to, or on top of, dolomite (Coetzee et al., 2007; Hobbs and Cobbing, 2007).

The Malmani Subgroup, which is dominated by dolomite, is situated in close proximity to the auriferous Witwatersrand Group in North West and Gauteng Provinces. Several gold mines in the Witwatersrand are situated in close proximity to karst aquifers, which in some instances had to be dewatered in order for mining to take place (Morgan and Brink, 1981, Warwick et al., 1987). The abstraction of water from mines and decant from abandoned mines have a major negative impact on the quality of the surface water and groundwater in Gauteng and North West Provinces. The massive dewatering of mines since the late fifties of the twentieth century has had (and still has) a detrimental effect on the natural aquatic systems in the area - one of the effects being the drying up of the springs of the Witwatersrand when the dewatering of the deep mines commenced decades ago (Enslin et al., 1996; Dreybrodt, 1996; Van Eeden, 1992). In its place, megalitres of water were pumped into certain rivers, which, together with sediments, changed the flow of those affected river systems.

\subsection{Sinkholes}

The dewatering of mines and the placement of slimes dams over the past century have caused several sinkholes in the West Rand and North West Province (Kleywegt and Pike, 1982; Pulles et al., 2005). Many of 
these sinkholes have not been rehabilitated, while new ones are still forming on the West Rand (Tempelhoff, 2007). Karstification occurs when the carbonate rock, which constitutes the karst system, dissolves when exposed to acids such as those contained in AMD or even weak acids that occur naturally. The result of this chemical decay is the formation of underground solution cavities, caves, sinkholes, and dolines. The increase of the AMD in the mine void in Gauteng and North West may cause excessive and rapid karstification in this area as dissolution of the dolomite takes place (Fourie, 2006; Hodgson et al., 2001; Krige, 2006; Swart et al., 2003; Van Eeden et al., 2008).

\subsection{Acid mine drainage (AMD)}

AMD is responsible for the most costly environmental and socio-economic impacts in South Africa (Oelofse et al., 2007). Mine effluent containing bimetals (including radioactive heavy metals), acid, and sulphates issues from mines in several ways: the run-off from slimes dams and rock dumps enters the surface water streams and groundwater, while water from slimes dams enters the groundwater of the underlying karst system on which they were built (Kleywegt, 1977). During 1997, South Africa produced an estimated 468 million tons of mineral waste per annum. Gold mining waste was estimated to account for 221 million tons or $47 \%$ of all mineral waste produced in South Africa, making it the largest single source of waste and pollution. There are more than 270 tailings dams in the Witwatersrand Basin, covering approximately $400 \mathrm{~km}^{2}$. These dams are mostly unlined and unvegetated, providing a source of dust, as well as soil and water pollution (Oelofse et al., 2007).

Mine effluent currently decants between 18 and 36 megalitres per day from an old Black Reef Shaft on the Old West Rand Consolidated Mine property (Harmony Gold Mine Limited), and an unqualified volume is still escaping downstream or into the groundwater (Fourie, 2006; Hobbs and Cobbing, 2007). The water quality of the river systems, wetlands, and groundwater in Gauteng and the North West Province has been deteriorating rapidly over the past five years due to mine effluent issuing from abandoned mines. After the mines on the Central Rand and several West Rand mines were abandoned, the water table has returned to its original level in the Western Basin Mine Void, which comprises an estimated volume of 45 million cubic metres. Several of the once dry springs have started to flow again since 2002, but are now issuing water polluted by mine effluent (Fourie, 2005). This affects not only the local springs and streams, but also major river systems further downstream. Mine effluent is already issuing from the 15 active and 29 closed mines to the north of the Vaal Barrage. AMD may continue for centuries after mines closure (Pullen, 1996).

Acidic mine water is currently decanting from a number of shafts into the Tweelopiespruit Catchment immediately to the north of the Wonderfonteinspruit and flows into the local dolomitic aquifer; the water level is still rising in this area and may decant into the Wonderfonteinspruit. This inflow would have a serious impact on any contaminated sites downstream, as was seen in the initial decant, where acid mine water was discharged into the Robinson Lake. The water decanting from the mine shaft and borehole into the Tweelopiespruit in 2002 had a $\mathrm{pH}$ of 2.6 due to AMD contamination (Fourie, 2005). Robinson 
Lake near Randfontein had a pH of 2.2 in May 2007 (Waterlab Report no. 19510), and the Tweelopiespruit just south of the Krugersdorp Nature Reserve had a pH of 2.7 in June 2007 (Waterlab Report no. 19766).

\subsection{Sulphates}

One of the characteristics of AMD is a high level of sulphates. If humans ingest more than $600 \mathrm{mg} / 1$ of sulphate, it may lead to vomiting and diarrhoea. The mine effluent from Harmony Gold had $4500 \mathrm{mg}$ of sulphates, $1200 \mathrm{mg}$ of iron, and $16 \mathrm{mg}$ of uranium per litre at the point of decant into the Tweelopiespruit in 2005 (Fourie, 2005). Hobbs (2007) reported sulphate concentrations as high as $4918 \mathrm{mg} / 1$, while Heyl (2007) reported concentrations of up to $5055 \mathrm{mg} / 1$ in the Tweelopiespruit.

\subsection{Metals}

The mean values for the sediment in the Wonderfonteinspruit and Tweelopiespruit Catchments exceed not only natural background concentrations, but also levels of regulatory concern. Some of these that are mobilised by AMD in these catchments are manganese, aluminium, iron, nickel, zinc, cobalt, copper, cadmium, arsenic, lead, radium, thorium, and uranium (Venter, 1995; Coetzee et al., 2006; Heyl, 2007). Any of these metals may be toxic depending on the time of exposure and the concentration of the metal an organism is exposed to (Hodgson et al., 2001; Adendorff, 1997). Factors such as salinity, acidity, and hardness of the water may determine the rate of accumulation of the metals by the organism (Moore and Ramamoorthy, 1984). The studies done on the effect of metals in AMD on organisms and ecosystems show that metals in water pose a serious health risk to invertebrates and vertebrates (Venter, 1995; Adendorff, 1997; Jooste and Thirion, 1999). The absorption of metals through the skin, gills, or ingestion may cause necrosis, tumours, cancer, and the impairment of several organ systems and, of course, death.

\subsection{Radioactivity}

Some of the metals contained in AMD such as uranium, thorium, radium, polonium, and some isotopes of lead are, in addition to being chemically toxic, also radioactive. Uranium is identified as the principal contaminant of concern emitted by the gold mining industry. Uranium is radioactive and chemically toxic with an extremely long half-life of $10^{10}$ years. Its impacts, after mine closure, on persons, property, and the environment are, therefore, long term and of appreciable magnitude. The presence of uranium was reported in the Wonderfonteinspruit (Coetzee et al., 2006; National Nuclear Regulator, 2007) and in the Tweelopiespruit (Heyl, 2007). Uranium and its daughter products have a long-term impact on the environment due to the fact that these elements accumulate in the sediments and will continue to leach out of the mine tailings and slimes dams for centuries to come (Winde and Van der Walt, 2004; Coetzee et al., 2006). Plants absorb these metals readily though their roots, and from there, they are passed on into the rest of the food web. 
According to Coetzee et al. (2006), the slimes dams of the West Rand and Far West Rand may contain more than 100000 tons of uranium. Coetzee et al. (2006) further estimate that as much as 50 tons of uranium is discharged annually from the gold mines of the West Rand and Far West Rand into the receiving water courses. Seepage and percolation from unlined tailings dams are responsible for the discharge of 24 tons of uranium into the receiving water courses. It was found that the uranium levels in the percolated water are 1000 to 1 million times higher than the background uranium levels. Twelve tons of uranium is released into the Wonderfonteinspruit Catchment from controlled and uncontrolled point discharges, and 10 tons of uranium is discharged by storm water annually. It is predicted that the sinkholes that were historically filled with uraniferous tailings will become secondary sources of uranium contamination of the groundwater and surface water after mine closure and cessation of pumping, when pre-mine flow patterns and volumes are restored (Coetzee et al., 2006).

The combination of the $\mathrm{pH}$ and redox-driven reactions resulted in a measured uranium concentration of $16 \mathrm{mg} / 1$ of the Robinson Lake and resulted in the NNR declaring the lake a radiation area. The background uranium concentration in water is $0.0004 \mathrm{mg} / 1$. In terms of the Department of Water Affairs and Forestry (DWAF) regulations for drinking water, the uranium concentration should not exceed $0.07 \mathrm{mg} / 1$ and, for irrigation, $0.01 \mathrm{mg} / 1$. The sediment in the Andries Coetzee Dam, a privately owned dam within the Lower Wonderfonteinspruit Catchment, contains uranium levels of $900 \mathrm{mg} / \mathrm{kg}$ while the sediment of the Upper Wonderfonteinspruit contains uranium levels of $1100 \mathrm{mg} / \mathrm{kg}$. The radioactive contamination of surface water bodies and groundwater in the Wonderfonteinspruit and Tweelopiespruit Catchments caused by the long-lasting mine water discharges and diffuse emissions of seepage and run-off from slimes dams poses radiological risks to people and the ecology. The use of water for drinking purposes may pose a direct threat to the communities dependent on the surface water and groundwater in the Wonderfontein and Tweelopiespruit Catchments. The threat of exposure to radioactive material is even greater when these radioactive materials are bioaccumulated by livestock drinking the contaminated water or through crops that are irrigated using contaminated water.

The measured uranium content of many of the fluvial sediments in the Wonderfonteinspruit, including those off mine properties and, therefore, outside the boundaries of licensed sites, exceeds the exclusion limit for regulation by the National Nuclear Regulator (NNR), which was set at $16 \mathrm{mg} / \mathrm{kg}$ of uranium (equivalent to an activity concentration of $0.2 \mathrm{~Bq} /$ g) before the publication of the Water Research Commission Report no. $1214 / 1 / 06$. It was found that the U-238 concentration of the sediment in the Tudor Dam is $10000-100000 \mathrm{~Bq} / \mathrm{g}$; at the Sluice and in the Andries Coetzee Dam, it is $1000-10000 \mathrm{~Bq} / \mathrm{kg}$; and at the Donaldson Dam, Harry's Dam, and the Attenuation Dam, it is $100-1000 \mathrm{~Bq} / \mathrm{g}$. The sites Tudor Dam, Lancaster Dam, Attenuation Dam, Donaldson Dam, Harry's Dam, and Andre Coetzee Dam had U-238 levels higher than the Nuclear Energy Act stipulation and, therefore, have a positive Tier 1 Risk Quotient. For approximately $50 \%$ of the 47 sites sampled, the calculated incremental doses of the respective critical group are between $1 \mathrm{mSv}$ and $100 \mathrm{mSv}$ per annum, the highest being $548 \mathrm{mSv}$ per annum calculated for the sample taken at Blyvooruitzicht Mine/Bridge 
Carletonville (National Nuclear Regulator, 2007). The prescribed maximum radioactive dosage to which an adult may be exposed per year is $1 \mathrm{mSv}$. After the publication of the WRC Report no. 1214/1/06, the $\mathrm{NNR}$ increased the regulatory control to $0.5 / \mathrm{Bq} / \mathrm{g}$.

Uranium-238 and its daughter products - Thorium-234, Protactinium234, Uranium-234, Thorium-230, Radium-226, Radon-222, Polonium-218, Lead-214, Bisthmuth-214, Polonium-214, Lead-210, Bismuth-210, and Polonium-210 - are alpha and beta particle emitters that have a damaging effect on tissues (Coetzee et al., 2006; Durakovic, 1999; Hursh et al., 1969; Kobert, 1906). The absorption of uranium may lead to kidney and liver failure (Garnier and Marke, 1921), and its neurotoxic effects include blindness, paralysis, and loss of coordination (Verne, 1931). Uranium may also cause mutations, aberrant sperm, connective tissue (including blood) diseases, changes in immune and endocrine systems, tumours, and cancer (Shanahan et al., 1966; Au et al., 1996; Baur, 1996; Conrad et al., 1996; Zaire et al., 1996; 1997).

The World Health Organisation provisionally recommended a maximum limit of $30 \mu \mathrm{g} / 1$ for uranium in drinking water in 2003. In the World Health Organisation Drinking Water Standards, which were revised in 2005, the toxicological limit for uranium in drinking water was lowered to $15 \mu \mathrm{g} / 1$. Konietzka et al. (2005) concluded that the safe limit for uranium in drinking water should be $2 \mu \mathrm{g} / 1$. The Bundesrat (German Federal Parliament) passed legislature in 2006 that limits the level of uranium in bottled water to $2 \mu \mathrm{g} / 1$, which it considers safe for the preparation of baby food. The maximum uranium concentration recommended in drinking water in South Africa, on the other hand, is $70 \mu \mathrm{g} / 1$ (North West Province, State of Environment Report, 2002). The uranium concentration in Robinson Lake is $16 \mathrm{mg} / 1$. If $0.284 \mathrm{mg} / 1$ is exceeded, human health may be at risk due to chemical toxicity (Kempster et al., 1996).

\subsection{Biodiversity}

AMD leads to the decimation of aquatic life in the water bodies into which mine effluent is discharged (Roback and Richardson, 1969; Jooste and Thirion, 1999; Adendorff, 1997; Van Staden, 2003). The SASS aquatic macroinvertebrate scoring system was devised as a quick assessment of the water quality to determine its potability by looking at the diversity, numbers, and type of macroinvertebrate (according to pollution sensitivity) present in the water. According to the diminishing in diversity and numbers of invertebrates in the Tweelopiespruit, the water quality rapidly deteriorates upstream along the Tweelopiespruit towards Harmony Gold Mine in Randfontein (Heyl, 2007; Hobbs and Cobbing, 2007). The pollution of the Tweelopiespruit and the Wonderfonteinspruit by AMD not only impacted negatively on the biodiversity of the region, but also on the health of the surviving organisms that are dependent on the water from the river or groundwater in the vicinity of the mines in that region. AMD-contaminated groundwater is used for irrigation in the vicinity of the mines. Metals and other pollutants are accumulated in organisms as they pass through the food chain. During the process of bioaccumulation, some toxins can become more concentrated as they travel up the food chain and have a detrimental effect on higher trophic levels (Kang et al., 1997). 


\section{Legal considerations and public responsibility regarding mine closure}

\subsection{Responsibilities, liabilities, and duties regarding mine closure}

Under section 34 of the National Environmental Management Act, No. 107 of 1998 (NEMA), if any party is convicted of an offence under an Act listed in Schedule 3 of the NEMA (which includes the National Water Act, No. 36 of 1998), and it appears that such a party has caused loss or damage to any other party, the court may determine the amount of loss or damage caused and may award damages or compensation equal to that amount in addition to other punishment such as the rehabilitation of the environment and taking steps to ensure that such damage would not occur again. Court costs may be claimed from the guilty party. Parties in such proceedings may rely on the common law remedies, including those available in terms of the law of delictual liability and the law of damages.

Whereas Acts of Parliament focus on the effects of activities, the basis of common law remedies, in negligence and nuisance, interferes with private property rights. As such, those remedies are available to the party that has suffered harm and not usually to third parties. The common law applies to all mining operations, whenever the licences or permits were obtained, unless modified by legislation. In common law, the landowner stands under no obligation to clean up contamination caused by another party on his or her property; nor is there a power vested in a local authority to order the landowner to clean contamination caused by a another party. However, should that landowner allow hazardous material that has accumulated on his or her property to escape and damage the property of another, the first landowner would be liable to the second under the rule in Lascon Properties (Pty) Ltd $v$ Wadeville Investment Co (Pty) Ltd and Another 1997 (4) SA 578 (W).

A remedy in nuisance would depend on the contamination escaping from the land that was subject to the mining and affecting other property. Arguably, it will also require a foreseeability of harm. The usual remedies where nuisance is established are damages or interdict. Even if the risk of harm to the plaintiff were foreseeable, liability would depend on what action could reasonably have been taken in all the circumstances to avert the risk. Further, the standard of care required is that of a reasonable person in the circumstances, there being a higher standard of care required of persons possessing special skills or expertise. In the case of tailings dams, a number of experts would have been involved in their design, construction, use, operation, maintenance, and closure. All of these experts would have been required to exercise a degree of care commensurate with their skill and experience.

A holder must apply for a closure certificate on lapsing or abandonment of his/her right/permit, cessation of mining operations, or relinquishment of any portion of land to which the right or permit relates. Within 180 days from these situations occurring, the holder must complete and submit a prescribed closing plan, including an environmental risk report, to the DME Regional Manager. Only after the Chief Inspector and DWAF have confirmed in writing that provisions have been complied with pertaining to health and safety and management of potential pollution to water resources may a closure certificate be issued 
and may the financial contribution or part thereof be returned.

\subsection{Responsibility and liability for historic and current pollution and ecological degradation}

Both the NEMA and the National Water Act (Act 36 of 1998) stipulate that a party has to take all reasonable measures to prevent pollution or degradation from occurring, continuing, or recurring as a result of mining operations for which it is responsible. According to these Acts, investigations, training, ceasing or modification of activities or processes, containment, and remediation have to be undertaken by the responsible party. The Mineral and Petroleum Resources Development Act (Act No. 28 of 2002) stipulates in section 38(1)(d) that the holder of the mining permit must take responsibility for the rehabilitation of the environment affected by mining to its natural state or to comply with the principle of sustainable development as far is reasonably practicable.

The Mineral and Petroleum Resources Development Act (MPRDA) deals with the responsibilities of holders of mining rights, permits, or permissions and states in section 38(1)(e) that such holder, whose mining causes or results in ecological degradation, pollution, or environmental damage that may be harmful to the health or well-being of anyone, "... is responsible for any environmental damage, pollution or ecological degradation as a result of his or her operations and which may occur inside and outside the boundaries of the area to which such right, permit or permission relates", and in terms of section 43(1), "remain responsible for any environmental liability, pollution or ecological degradation and the management thereof until a closure certificate has been issued".

Section 19 of the National Water Act (NWA) deals with prevention and remedying effects of pollution and states in subsection 19(1) that "an owner of land, a person in control of land or a person who occupies or uses the land on which- (a) any activity or process is or was performed or undertaken; or (b) any other situation exists, which causes, has caused or is likely to cause pollution of a water resource, must take all reasonable measures to prevent any such pollution from occurring, continuing or recurring". Section 28 of the NEMA deals with the duty of care towards pollution prevention and remediation.

Under the MPRDA, NEMA, and by implication the NWA, liability is specifically extended to the director of the mining company concerned in his or her personal capacity, that is, personal liability: MPRDA, section 38(2): "Notwithstanding the Companies Act, No 61 of 1973, or the Close Corporations Act No 69 of 1984, the directors of a company or members of a close corporation are jointly and severally liable; for any unacceptable negative impact on the environment, including damage, degradation or pollution; advertently or inadvertently caused by the company or close corporation which they represent or represented."

NEMA, section 34(7), states that any person who is or was a director of a mining company at the time of the commission by that mining company of an offence under a provision listed in Schedule 3 (this includes the NWA) will be guilty in his/her personal capacities of the offence and liable on conviction to the penalties imposed if the offence in question resulted from the failure of the director to take all reasonable steps that 
were necessary under the circumstances to prevent the commission of the offence by the mining corporation. Proof of the said offence by the firm under the Schedule 3 provision shall constitute prima facie evidence that the director is guilty.

All three statutes, furthermore, establish a joint and shared liability and prevent liability from being contracted out. The MPRDA, however, provides for the transfer of environmental liabilities in section 43(2) in a particular manner: on written application in the prescribed manner by the holder of a right or permit, the Minister may transfer such environmental liabilities and responsibilities as may be identified in the Environmental Management Programme and closure plan to a person with such qualifications as may be prescribed. These prescriptions are contained in Regulations 58 and 59 of the MPRD Regulations (GNR527). The provision relating to the transfer of liability under the MPRDA does not, however, imply that it can be contracted out, as described above.

Apportionment of liability is provided for in the NEMA and the NWA, but not under the MPRDA, since the holder of the right or permit is deemed to be the responsible person. If more than one person is liable under the NWA, "the responsible authority (DWAF or CMA /Catchment Management Agency]) must apportion the liability, but such apportionment does not relieve any of them of their joint and several liability for the full amount of the costs" (section 19(8)). Liability may also be apportioned by the Department of Environmental Affairs and Tourism (DEAT) in terms of NEMA, section 28(11): if more than one person is liable, "... the liability must be apportioned among the persons concerned according to the degree to which each was responsible for the harm to the environment resulting from their respective failures to take the measures required".

Bosman and Kotze (2005) state that an applicant for a mining right or permit must also make financial provision for remediation of environmental damage or management of negative environmental impacts in terms of the MPRDA prior to approval of his/her environmental management plan (EMP). The liabilities and contribution to the financial provision must be assessed annually, and the Minister of the Department of Minerals and Energy (DME) may appoint an independent assessor if necessary. The requirement to maintain and retain financial provision remains in place until a closure certificate has been issued, but the Minister may retain such portion of the financial provision as may be required to rehabilitate the closed mining operation in respect of latent or residual environmental impacts (section 41(5)).

The MPRD Regulations prescribe the requirements to obtain a closure certificate. An application for mine closure (Regulation 57) must be accompanied by a closure plan and an environmental risk report. The closure plan (Regulation 62) forms part of the EMP and must include, inter alia:

- A description of the closure objectives and how these relate to the prospecting or mine operation and its environmental and social setting. Closure objectives (Regulation 61) form part of the draft EMP (and are, therefore, established before mining commences or on application for the mining right or permit) and must identify the key objectives for mine closure to guide the project design, development, and management of environmental impacts, 
provide broad future land objectives for the site, and provide proposed closure costs;

- A sketch plan drawn on an appropriate scale describing the final and future land use proposal and arrangement for the site;

- A summary of the regulatory requirements and conditions for closure negotiated and documented in the EMP;

- A summary of the results of the environmental risk report and details of identified residual and latent impacts;

- A summary of the results of progressive rehabilitation undertaken;

- The mitigation or management strategy proposed to avoid, minimise, and manage residual or latent impacts;

- Details of any long-term management and maintenance expected as well as a proposed closure cost and financial provision for monitoring, maintenance, and post-closure management;

- A record of interested and affected parties consulted.

Bosman and Kotze (2005) state that the MPRDA is the only South African Act that specifically indicates the end point of remediation, which also incorporates the concept of sustainable sequential land use and use of other resources such as water in the statutory framework. It is stipulated by this Act that interested and affected parties must be involved in the agreement on the future land use of areas impacted on by mining.

Regulation 56 of the Mineral and Petroleum Development Regulations (MPDR) prescribes the principles for mine closure as follows: "In accordance with applicable legislative requirements for mine closure, the holder of a mining right or mining permit must ensure that-

- The closure of a mining operation incorporates a process which must start at the commencement of the operation and continue throughout the life of the operation;

- Risks pertaining to environmental impacts must be quantified and managed, which includes the gathering of relevant information throughout the life of a mining operation;

- The safety and health requirements of the Mine Health and Safety Act 29 of 1996, are complied with;

- Residual and possible latent environmental impacts are identified and quantified;

- The land is rehabilitated, as far as is practicable, to its natural state, or to a predetermined and agreed standard or land use which conforms with the concept of sustainable development and

- Mining operations are closed efficiently and cost effectively."

This implies that, before a decision is taken on which measures to implement for remediation and closure, the objectives that need to be achieved with the implementation of such measures must be established 
and agreed on. This corresponds to the MPRD Regulations objectives for mine closure stated above: "the land is rehabilitated, as far as is practicable, to its natural state, or to a predetermined and agreed standard or land use which conforms [to] the concept of sustainable development." Such objectives would include, from a generic perspective, the following:

- Immediate harm to human health and safety must be eliminated;

- Groundwater must be fit for current and future domestic and other uses consistent with agreed current and future land use;

- Surface water must be fit for current and future basic human needs and aquatic ecosystems requirements;

- Risk of harm to non-aquatic organisms (vegetation) must be eliminated; and

- Soil (property) must be fit for use consistent with current and future land use.

Specific objectives must be established for each of these aspects at individual sites. In this context, it is, therefore, impossible to determine whether measures taken to remediate environmental impacts with the aim of achieving mine closure are, in fact, "reasonable measures", unless the future land use has been determined and objectives for remediation have been agreed on (Bosman and Kotze, 2005).

\section{Environmental and societal concerns and considerations}

In a study of destructive environmental practices such as toxic crimes and other environmental injustices, it appears evident that claims are rarely successful due to the lack of evidence (Burns and Lynch, 2002). Therefore, research on corporate crime has been neglected for many years because of this lack of data. The effects of environmental pollution can take years to emerge as in the case of cancer that may be caused by invisible pollutants. Often reports on pollution that is treated by bureaucrats as "secret" or "confidential" are purposefully kept from the public, which is directly affected by the pollution.

Current mine closures need to be addressed with urgency. All mines have a finite lifespan, and a large number of mines have already reached the end of production and are often left in a derelict and abandoned condition. In terms of the official statement by the DME, there are approximately 8000 derelict and ownerless mines, which would take 800 years to rehabilitate at a current cost of R100 billion (Brown, 2007). This figure is only an estimate and certainly excludes the cost of the treatment of polluted groundwater and human health, loss of earnings, and social disruption. Environmental and social impacts manifest after mining commences, but worsen rapidly once mine closure is reached and no further funds are available for remediation. Typically, environmental and social costs are not balance sheet items, being kept away from investors, effectively shifting the cost of rehabilitation onto society. The negative effects of the mines will reach their climax over tens if not hundreds of years.

The Federation for a Sustainable Environment made an oral and written submission of the official findings from public domain reports on 4 June 
2008 to Ms C September, the Chairperson of the Parliamentary Portfolio Committee on Water Quality and Pollution. In response, the Minister of Minerals and Energy, Bulyewa Sonjica, said in her Budget Speech before Parliament on 6 June 2008: "Following reports of possible radiological contamination in the Wonderfonteinspruit Catchment area, the National Nuclear Regulator instituted an investigation. The investigation indicated that the situation does not pose a radiological risk to the surrounding communities."

Government is currently finding it very difficult to engage the mining sector regarding this problem, with many mining companies refusing to accept responsibility for AMD and related environmental problems. The Wonderfontein Regulators Steering Committee (WRSC) was founded on 21 December 2007 as a result of the oppositional activism of the Federation for a Sustainable Environment with support of the Legal Resource Centre, CANSA, the CSIR, and researchers and community groups such as the Public Environmental Arbiters, Potchefstroom Petitioners, Pelindaba Working Group, groundwork, Earthlife, Fochville Concerned Residents, and the Randfontein Environmental Action Group.

It was aspired that this committee, together with officials of all the relevant government departments as well as from the local municipalities, would steer the whole remediation process and that the NNR would chair the WRSC. It was aspired that the NNR would have stricter control over the discharges from the mines and that DWAF would ensure that all water use licences be issued to the mines as soon as possible in an endeavour to stop contamination of the Tweelopiespruit and Wonderfonteinspruit. All regulators agreed that remediation of the hot spots was required. A team of experts (TOX) was appointed by government to determine the priority hot spots, but this was done without public participation or community engagement. The WRSC, furthermore, aspired that the mines would be approached to contribute financially towards the remedial work to be done as per the findings of the TOX and that the community would be involved in this regard.

\section{The only progress that has been made so far is the appointment of the TOX. The problems that remain are:}

- Uncertainties regarding the method followed in the appointment of this team, its terms of reference, its source of remuneration, the credentials of its individual members, etc.;

- Radioactive hot spots remain unrehabilitated, unremediated, unmitigated;

- The public continues to be exposed to radioactive hot spots without intervention from the mines or government;

- The mines are still operating without water use licences;

- The majority of affected communities are still excluded from the consultation processes;

- The NNR is visibly absent from all water forum meetings and committees;

- Point source pollution continues without enforcement of the "polluter 
pays" principle;

- Habitual non-compliance with the DWAF and NNR directives remains unpunished;

- The mines have not agreed to contribute financially towards remedial work;

- Affected landowners continue to suffer significant pecuniary losses and health risks.

It is evident that mine closure poses a number of challenges to the environment and groundwater legislation. The gold mines within the West Rand and Far West Rand are in close proximity, resulting in a hydrological confluence that makes it difficult, if not impossible, to consider the water-related closure risks in isolation. Most of the gold mines are exposed to the inflow of extraneous water into the underground workings. The aquifers affected by the subsequent dewatering vary from one basin to the next, as do the associated environmental problems (Pulles et al., 2005).

From a review of Mine Environmental Management Programme Reports, none of the gold mining companies (DRD Gold, AngloGold Ashanti, GoldFields, Harmony Gold) operating within the West Rand and Far West Rand operate according to an approved aligned environmental management plan (EMP) in terms of the Mineral and Petroleum Resources Development Act (Act No. 28 of 2002) (Kruger; Rex and Ellis; Wookay; Zorab, 2008).

According to Pulles et al. (2005), the surface residue deposits (tailings dams and waste rock dumps) that remain after mine closure can never be maintained in a completely reducing environment and must be considered to pose a potential water-related risk. While most mines recognise the fact that tailings dams generate AMD, it is generally and incorrectly assumed that the impact will decrease to acceptable levels when mining operations cease. The assessment of long-term risks from tailings dams can at best be described as subjectively qualitative in nature, and no proper quantitative assessments are reported in any of the Environmental Management Programme Reports (EMPR).

According to Pulles et al. (2005), waste rock dumps have very large inventories of fine material that are much more permeable to oxygen than tailings dams. These authors are also of the opinion that the secondary source of contaminants that remain in the soil after a dump has been removed appears to be universally ignored, and it is assumed that removal of the dump removes all potential for pollution from that site. Pulles et al. (2005) also state that most mines appear to have some monitoring programme to evaluate shallow aquifer and surface water impacts from the surface residue deposits. However, the monitoring programmes are not clearly stipulated in the EMPR documents, and hence, it is unclear what the extent of contaminant plumes is.

Very few specialist investigations appear to have been done to identify the status of the geohydrological regime, the extent of contamination, preferential pathways, and predictions regarding long-term migration. As a result, there are very limited mitigation or management options described in the EMPRs that specifically deal with the containment or rehabilitation of contaminated groundwater. The potential impact on 
the groundwater from other surface contaminant sources such as the metallurgical plants and domestic and industrial waste sites is not described. Many of the EMPR documents state that these structures will be removed or rehabilitated during decommissioning, but it is not stated whether they had an impact on the environment and whether groundwater rehabilitation is required.

Some of the older mines were subjected to amalgamations and changes in ownership (for example, DRD Gold - joint ventures with Mintails, Blyvooruitzicht Gold Mining Company; Harmony Gold - joint venture with Pamodzi Holdings, known as Rand Uranium, and sale of assets to Moira Mining; Goldfields' Kloof, including Leeudoring, and East Driefontein and West Driefontein were consolidated, etc.), and in several instances, the surface infrastructure, including some tailings and rock dumps, was sold to third parties. Many of the current mine EMPR documents exclude infrastructure that has been sold, and it is not clear whether the new owners are required to address groundwater contamination and whether it is, in fact, being done.

\section{Conclusion}

This paper has illuminated some of the many environmental and socioeconomic issues that have to be addressed by government and the mines before mine closure can take place on the West Rand. It is evident that researchers from a variety of disciplines have an important role to play in order to help solve what we consider to be a national crisis. It is essential that environmental justice should triumph in order to secure a healthier environment for those who live in it, if not for the sake of the environment itself (Van Eeden, 2008b).

\section{In the light of the overwhelming evidence that:}

- the water of the Tweelopiespruit and the Wonderfonteinspruit is polluted by the gold and uranium mines of Gauteng and the West and Far West Rand,

- the water contains unacceptable levels of acid, sulphates, and metals,

- the water and sediment contain radionucleotides such as uranium in excess of 15 micrograms per litre, which is the prescribed maximum allowed by the WHO for human consumption (World Health Organisation, 2005),

- high levels of pollutants, especially in combination with one another, cause the degradation of the aquatic ecosystem, and

- the pollution emanating from the mines poses a threat to the health of humans and other organisms that depend on that water source,

it is incomprehensible that the Department of Health, DWAF, DEAT, and DME refuse to acknowledge this crisis in public or deal with this crisis decisively, but rather prefer to act with ignorance and rather chase smallscale industries for some kind of artificial success in the field of environmental preservation. Many thousands of people and their livestock depend on the rivers and groundwater from the Tweelopiespruit and Wonderfonteinspruit Catchments (Oelofse et al., 2007; Van Biljon, 2007). 
The government's refusal to take punitive steps against the mines that polluted and are still polluting this water resource and the land surrounding it or to force them to rehabilitate the areas that are affected by mining activities stands in conflict with the Constitution of South Africa. The Constitution of South Africa (Act No. 108 of 1996) supersedes any other Act of Parliament. It is the moral duty of the government to look first and foremost at the well-being of its citizens and preservation of the environment before catering for the financial needs of multinational companies.

The efforts of many specialists have failed to address and solve the problem of mine pollution, which has delayed mine closure so far because most have been working in isolation with relatively little interaction with specialists from other disciplines or the community. The cooperation between geologists, hydrologists, biologists, ecologists, health practitioners, human rights activists, sociologists, historians, environmentalists, legal practitioners, the media, and the community is necessary to address this multifaceted problem and to find a solution to one of the most serious ecological threats that faces South Africa.

\section{References}

Adendorff, A. (1997) Effects of mining activities on selected aquatic organisms, Unpublished PhD Thesis, Rand Afrikaans University, Johannesburg, 253p.

Adler, R.A.; Claassen, M.; Godfrey, L. And Turton, A. (2007) Water, mining, and waste: an historical and economic perspective on conflict management in South Africa. The Economics of Peace and Security Journal, 2(2), pp. 33-41.

Attfield, R. (1983) The ethics of environmental concern. Blackwell, Oxford.

Attfield R. (1994) Environmental philosophy Avebury, Aldershot.

Au, W.W., Wilkinson, G.S., Tyning, S.K., Legator, M.S., Al Zein R., Hallberg, L. and Heo, M.Y. (1996) Monitoring populations for DNA repair deficiency and for cancer susceptibility. Environmental Health Perspectives, 104 Supplement 3, pp. 579-584.

Baur, X., Rihs, H.P., Altmeyer, P., Degens, P., Conrad, K. and Mehlhorn, H. (1996) Systemic sclerosis in German uranium miners under special consideration of antibody subsets and HLA Class II alleles. Respiration, 63, pp. 368-375.

Benton, L.M. and Short, J.R. (2000) Environmental discourse and practice. Blackwell Publishers p. 147.

Bosman, C. and Kotze, L.J. (2005) "Responsibilities, Liabilities and Duties for Remediation and Mine Closure under the MPRDA and NWA". Water Institute of Southern Africa, Mine Water Division.

Bredenkamp, D.B. and Xu Y. (2003) "Perspectives on recharge estimation in dolomitic aquifers in South Africa", In: Groundwater recharge estimation in Southern Africa (Xu, Y and Beekman HE, eds.) UNESCO International Hydrological Programme Series no. 64, UNESCO, Paris, pp. 65-79. 
Brown, J. (2007) Derelict Mines to Cost State R100bn, Business Report, 23 May 2007.

Bundesrats-Drucksache (2006) 711/06 v. 12.10.2006; 828. Sitzung v. 24.11.2006.

Burns, R.G. and Lynch, M.J. (2002) "Environmental crime". A source book, pp. 2-3.

Council for Geoscience Archive, Minutes, Far West Rand Dolomitic Water Association (FWRDWA), 1964-1994.

Council for Geoscience Archive, Documents, State Coordinating Technical Committee (SCTC), 1964-2004).

Conrad, K., Mehlhorn, J., Luthre, K., Dorner, T. and Frank, K.H. (1996) Systemic lupus erythematosus after heavy exposure to quartz dust in uranium mines: clinical and serological characteristics. Lupus, 5, pp. 62-69.

Coetzee, H., Winde, F. and Wade, P.W. (2006) "An assessment of sources, pathways, mechanisms and risks of current and potential future pollution of water and sediments in gold-mining areas of the Wonderfonteinspruit catchment". Water Research Commission, Report No. 1214/06.

Dreybrodt, W. (1996) "Principles of early development of karst conduits under natural and man-made conditions revealed by mathematical analysis of numerical models". Water Resources Research, 32, pp. 2923-2935.

Durakovic, A. (1999) "Medical Effects of Internal Contamination with Uranium. Croatian Medical Journal, 40(1), pp. 49-66.

Enslin, J.F. , Kleywegt, R.J. , Beukes, J.H.T. and Gordon-Welsh, J.F. (1976) "Artificial recharge of dolomitic ground-water compartments in the Far West Rand Gold Fields of South Africa". Geological Survey of South Africa, Report 0249.

Fourie, M. (2005) “A rising acid tide". Johannesburg Mail and Guardian, South Africa, 12 April 2005.

Funke, N.; Nortje, K. Findlater, K.; Burns, M.; Turton, A.; Weaver, A. and Hattingh, H. (2007) "Redressing inequality: South Africa's new water policy". Environment 4(1), 2007, pp. 141-146.

Fourie, W. (2006) "Impact of the discharge of treated mine water, via the Tweelopies Spruit, on the receiving water body Crocodile River System, Mogale City, Gauteng Province". DWAF 16/2/7/C221/ $\mathrm{C} / 24$. Environmental Impact Document prepared for Harmony Gold Mining Limited.

Garnier, M. and Marke, J. (1921) L'intoxication chronique par le nitrate d'urane en injection quotidienne chez le lapin. Comptes rendus des seances de la societe de biologie et des filiales (Paris), 107, pp. 938-940.

Goudswaard, B. (1979) Capitalism and progress, Eerdmans, Grand Rapids, p. 50 . 
Graham, L.P (2007) "The effect of acid mine drainage on the cave-dwelling amphipod, Sternophysinx filaris: A case study for the use of these amphipods as bioindicators", Unpublished BSc Honours research report, Department of Zoology, University of Johannesburg, 37 p.

Gutmann, A. and Thompson, D. (2006) Ethics and politics. Thomson \& Wadsworth, UK, pp. 261-263.

Heyl, A.J. (2007) "Effect of mining effluent on the distribution of fresh water invertebrates in the Tweelopiespruit, Gauteng". Unpublished BSc Honours research report, Department of Zoology, University of Johannesburg, 24 p.

Hobbs, P.J. and Cobbing, J.E., (2007) "A hydrogeological assessment of acid mine drainage impacts in the West Rand Basin, Gauteng Province”. Rep. no. CSIR/NRE/WR/ER/2007/ 0097/C.CSIR.

Hodgson, F.D.I., Usher, B.H., Scott, R., Zeelie, S., Cruywagen, L.M. and De Necker, E. (2001) "Prediction techniques and preventative measures relating to the post-operational impact of underground mines on the quality and quantity of groundwater resources", Water Research Commission of South Africa, Report No. 699/1/ 01 .

Hursh, J.B., Neuman, N.F., Toribara, T., Wilson, H. and Waterhouse, C. (1969) "Oral ingestion of uranium by man". Health Phys.,17(4), pp. 619-621.

Jooste, S. and Thirion, C. (1999) "An ecological risk assessment for a South African acid mine drainage", Water Science and Technology 39(10-11), pp. 297-303.

Kang, Y.-S., Matsuda, M., Kawano, M., Wakimoto, T.and Min, B.-Y. (1997) "Organochlorine pesticides, polychlorinated biphenyls, polychlorinated dibenzo-p-dioxins and dibenzofurans in human adipose tissue from western Kyungnam, Korea". Chemosphere, 35, pp.2107-2117.

Kempster, P.L.; Van Vliet, H.R.; Looser, U.; Parker, I.; Silberbauer, M.J. and Du Toit, P. (1996) "Overview of radioactivity in water sources: uranium, radium and thorium". Final report, IWQS-No:N/0000/ 00/RPQ/0196, Pretoria.

Kleywegt, R.J. (1977) "Memorandum oor die moontlike gevaar wat geskep word deur water vanaf die 'Western Areas Gold Mining Co. Ltd.' na die Rietspruit te laat vloei”. Geological Survey of South Africa Technical Report No. 0141.

Kleywegt, R.J., Pike, D.R. (1982) "Surface subsidence and sinkholes caused by lowering of the dolomitic water-table on the Far West Rand Gold Field of South Africa”. Annals of the Geological Survey of South Africa. $16 \mathrm{p}$.

Kobert, R. (1906) "Lehrbuch der Intoxikationen 2". Stuttgart: Ferdinand Enke Publishing, pp. 321-323.

Konietzka, R. Dieter, H.H. and Voss, J-U. (2005) "Vorschlag für einen gesundheitlichen Leitwert für Uran in Trinkwasser". In: Umweltmedizin in Forshung und Praxis 10, pp. 133-143. 
Krige, G. (2006) "Hydrological/chemical aspects of the Tweelopie/Riet/ Blaauwspruit with specific refence to the impact water, decanting from the Western Basin Mine Void has on the system". EIA Report prepared for Harmony Gold Mining Limited.

Kruger, K. (2008) "DRD Gold” - Personal communication with M. Liefferink.

Moore, J.W. and Ramamoorthy, S. (1984) Heavy metals in natural waters. Applied monitoring and impact assessment. Springer-Verlag, New York, p. 268.

Morgan, D.J. and Brink, A.B. (1984) “The far West Rand dolomites". In: Proceedings of the International Conference on Ground Water Technology, Johannesburg, South Africa, 2, pp. 554-573.

National Nuclear Regulator (2007) "Radiological impacts of the mining activities to the public in the Wonderfontein Catchment area". Report No TR-RRD-07-0006.

Oelofse, S.H.H., Hobbs, P.J., Rascher. J. and Cobbing, J.E. (2007) "The pollution and destruction threat of gold mining waste on the Witwatersrand - a West Rand case study". Paper presented at the 10th International Symposium on Environmental Issues and Waste management in Energy and Mineral Production (SWEMP, 2007), Bangkok 11-13 December 2007.

Pulles, W., Banister, S., Van Biljon, M. (2005)“The Development of Appropriate Procedures towards and after closure of underground gold mines from a water management perspective", Water Research Commission Report No 1215/1/05.

Pullen, A.W. (2006) "Acid mine drainage. Approved Environmental Management Programme Subsection 2.9.2.2, SRK REPORT 196369/G/1 - Deelkraal Mine', p.44.

Rex, H. and Ellis, J. (2008) "AngloGold Ashanti and WSP Environmental", Personal Communication.

Roback, S.S. and Richardson, J.W. (1969) "The effects of acid-mine drainage on aquatic insects". Proceedings of the Academy of Natural Sciences of Philadelphia, 121, pp. 81-99.

Shanahan, E.M., Peterson, D., Roxby, D., Quintana, J., Morely, A.A. and Woodward, A. (1966) "Mutation rates at the glycophorin A and HPRT loci in uranium miners exposed to radon progeny". Occupational and Environmental Medicine, 53, pp. 439-444.

Smith, M.J. and Heath, A.G. (1979) "Acute toxicity of copper, chromate, zinc and cyanide to freshwater fish: Effect of different temperatures", Bulletin of Environmental Contaminant Toxicology 22, pp. 113-119.

Swart, C.J.U., James, A.R., Kleywegt, R.J. and Stoch, E.J. (2003) "The future of the dolomitic springs after mine closure on the Far West Rand, Gauteng, RSA". Environmental Geology, 44(7), pp. 751-770.

Tempelhoff, E., (2007) "Nog ' $\mathrm{n}$ reuse gat op grond van Harmony Gold ontdek", Beeld 24 July, 2007.

Van Biljon, M. and Krige, G. (2005) "Cost apportionment for the treatment 
of contaminated water decanting from the Western Basin mine void". Report for Harmony Gold Mining Limited.

Van Biljon, M. (2007) "Geohydrological Review of the potential impact on the Sterkfontein dolomite during increased surface water runoff, April 2006 - February 2007". Report prepared for Johan Fourie \& Associates for Harmony Gold Mining Limited.

Van Eeden, E.S. (1992) "Ekonomiese ontwikkeling en die invloed daarvan op Carletonville, 1948-1988: 'n Historiese studie", Unpublished PhD dissertation, Potchefstroom University for Christian Higher Education.

Van Eeden, E.S. (2006) "Whose environment? whose nature? - a transdisciplinary discussion on some inhumane actions in the destruction and construction in nature - case study, the Merafong municipal region", The Journal for Transdisciplinary Research in Southern Africa, 2(2), Dec.

Van Eeden, E.S. (2007a) "Past and present actions of environmental heritage by NGO's in the controversial Wonderfontein Catchment, Gauteng- a critical assessment”. New Contree, 53, May 2007, pp. 55-80.

Van Eeden, E.S. (2007b) "Is die regering omgewingsgroen of ' $n$ boelie? " $n$ Beknopte perspektief op omgewingsbewaring in die eertydse Verre Wesrand (tans Gauteng)", Woord en Daad, Lente\&Somer, 2007, pp. 24-34.

Van Eeden, E.S. and I Brink (2007) "Factors that determine the facilitation of stakeholders and roleplayers in environmental management - some philosophical-historical thoughts with the Merafong area as example”, Koers (4) 2007, pp. 334-365.

Van Eeden, E.S. (2008a) "Weaknesses in environmental action in South Africa: A historical glance on the West Rand (Gauteng Province)", International Journal of Water Resources Development, 24(3) pp. 463475.

Van Eeden, E.S. (2008b) Conceptual 'envirobusion' in 21 st century environmental issues in South Africa: past practices abusing present thought, New Contree, 55, pp. 105-135.

Van Eeden, E.S.; Liefferink, M. \& Tempelhoff, E. (2008) "Environmental ethics and crime in the water affairs of the Wonderfontein Spruit Catchment, Gauteng, South Africa", The Journal for Transdisciplinary Research in Southern Africa, 4(1), pp. 31-58.

Van Staden, S. (2003) "A case study on the use of habitat assessments and biological indices for the management of recreational stream fisheries", Unpublished MSc Dissertation, Rand Afrikaans University, Johannesburg. $112 \mathrm{p}$.

Venter, A.J.A. (1995) "Assessment of the effects of gold-mine effluent on the natural aquatic environment". Unpublished PhD Thesis. Rand Afrikaans University, Johannesburg. 59p.

Verne, J. (1931) "Lesions histologiques des centres nerveux superieurs chez le lapins soumis a l'intoxication chronique part l'urane". 
Annales d'anatomie pathologique, 8, pp.757-758.

Warwick, D.W., Brackley, I.J., Connelly, R.J. and Campbell, G. (1987) "The dewatering of dolomite by deep mining in the West Rand, South Africa". In: Barry, B., Wilson, W.L. (eds.), Karst hydrogeology: engineering and environmental applications, Proceedings of the 2nd Multidisciplinary Conference on Sinkholes and Environmental Impacts of Karst, Orlando, USA, pp. 349-358.

White, L. (1970) “The historical roots of our ecological crisis" In: De Bell, G. ed., The environmental handbook, Ballantine, New York, pp. 1826.

Winde, F. and Van der Walt, I.J. (2004) "The significance of groundwaterstream interactions and fluctuating stream chemistry on waterborne uranium contamination of streams - a case study from a gold mining site in South Africa". Journal of Hydrology, 297, pp.178-196.

Wookay, R. (2008) Manager Group Corporate Affairs and Corporate Communication, GoldFields - Personal Communication with M. Liefferink.

World Health Organization (2003) Uranium in drinking-water. Background document for preparation of WHO Guidelines for drinking-water quality. Geneva, World Health Organization (WHO/ $\mathrm{SDE} / \mathrm{WSH} / 03.04 / 118$ ).

World Health Organization (2005) WHO guidelines for drinking-water quality.. Uranium in drinking water. http://www.who.int/ water_sanitation_health/dwq/chemicals/uranium290605.pdf

Zaire, R., Griffin, C.S., Simpson, P.J., Papworth, D.G., Savage, J.R. and Armstrong, S. (1996) "Analysis of lymphocytes from uranium mine workers in Namibia for chromosomal damage using fluorescence in situ hybridization". Mutation Research 371, pp. 109-117.

Zaire, R., Notter, M., Riedel, W. and Thiel, E. (1997) "Unexpected rates of chromosomal instabilities and alterations of hormone levels in Namibian uranium miners". Radiation Research147, pp.579-584.

Zorab, R. (2008), Harmony Gold - Personal Communication with M. Liefferink. 